\title{
Development and egg production in Centropages typicus (Copepoda: Calanoida) fed different food types: a laboratory study
}

\author{
D. Bonnet ${ }^{*, * *}$ F. Carlotti ${ }^{*}$ \\ Laboratoire d'Océanographie Biologique et d'Ecologie du Plancton Marin, ESA7076, Station Zoologique, Quai de la Darse, \\ BP 28, 06230 Villefranche-sur-mer, France
}

\begin{abstract}
The effects of different types of food on the growth, development, reproduction, egestion and grazing of the copepod Centropages typicus Krøyer was studied in the laboratory at $15^{\circ} \mathrm{C}$. The copepods were reared from eggs to NVI using Isochrysis galbana as food, and from NVI onwards with a range of diets: a single food source consisting of 1 of 2 algae (the haptophyceaen $H y$ menomonas elongata and the diatom Thalassiosira weissflogii), a single food source consisting of the ciliate Strombidium sulcatum, and a mixture consisting of each type of algae and the ciliate. The results, based on daily sampling, show that growth, development rate and egg production were dependent on food type. The food types that induced the shortest development times (H. elongata, S. sulcatum) did not necessarily result in the highest production rates. The daily specific growth rate for copepodid stages was significantly lower with $T$. weissflogii $\left(0.045 \mathrm{~d}^{-1}\right)$ than with the other diets $(0.09$ to $0.15 \mathrm{~d}^{-1}$ ). The combination of variable development and variable growth rates with the different diets induced a high variability in mean weight within developmental stages. The weights recorded are amongst the highest observed for this species. Length did not differ significantly within the same development stage between different diets. Mixed food sources were more efficient than a single food source in terms of egg production and viability. No relationship was established between hatching success, female age or copepodid mortality rate and food type. A pure diet of $T$. weissflogii resulted in a sex ratio skewed towards males, whereas the other diets produced a balanced sex ratio. The present results indicate the mixture phytoplankton/ciliate to be the most favourable for development, growth and egg production, suggesting that omnivory is the best feeding strategy for C. typicus.
\end{abstract}

KEY WORDS: Centropages typicus · Development - Growth · Egg production · Hatching rate · Phytoplankton prey $\cdot$ Microzooplankton preyos

\section{INTRODUCTION}

The importance of food quality has been demonstrated by many authors studying a range of processes in copepods: e.g. ingestion and assimilation (Paffenhöfer 1971, Checkley 1980, Cowles et al. 1988, Klein Breteler et al. 1990, Reinfelder \& Fisher 1991), egg production and hatching success (Checkley 1980, Ianora \&

\footnotetext{
*Present address: Laboratoire d'Océanographie Biologique, 2 rue du Professeur Jolyet, 33120 Arcachon, France

**E-mail: d.bonnet@biocean.u-bordeaux.fr
}

Poulet 1993, Miralto et al. 1995, 1999, Jónasdóttir \& Kiørboe 1996) and faecal pellet production (Ianora \& Poulet 1993, Butler \& Dam 1994). A few major studies have demonstrated an influence of food quality on their life cycle (Klein Breteler et al. 1990, Støttrup \& Jensen 1990, Twombly \& Burns 1996, Koski et al. 1998, Twombly et al. 1998). Kleppel (1993) stated that dietary diversity is a nutritional requirement, which changes ontogenetically from copepodid to adult stage. Juvenile copepods must feed on different food size spectra during the course of their development (Berggreen et al. 1988, Klein Breteler et al. 1995), as the adult is about 10 
to 20 times larger than the Nauplius I. Moreover juveniles have different bioenergetic needs linked to their various developmental stages (growth, appearance of sexual characters, reproduction).

Thus, the growth and reproduction of these organisms depends on their present and recent-past feeding history in terms of both food quantity and food quality. However, apart from their recent feeding history, nothing is known about the previous nutrition of individuals in the majority of developmental studies in the laboratory (Mayzaud et al. 1998).

The role of protozoans in the zooplankton diet has been little studied in the laboratory, since they are not easily detectable in the gut contents of zooplankton collected in the field (Stoecker \& Govoni 1984). Nevertheless, in situ studies have shown the importance of microzooplankton (Azam et al. 1983), which consume primary production in a size spectrum inaccessible to copepods, and then serve as prey for the mesozooplankton. For most copepods, omnivory seems to be a frequent strategy (Corner et al. 1974, Paffenhöfer \& Knowles 1980, Dam et al. 1994), as demonstrated by fatty acid and amino acid tracers (Ederington et al. 1995), and predation on protozoans is thought to be important, since they consitute a source of nutrients essential for survival and production (Ohman \& Runge 1994).

Laboratory studies on the development of Centropages typicus (Smith \& Lane 1985, Davis \& Alatalo 1992) have not considered microzooplankton prey as a food source. In the laboratory, Wiadnyana \& Rassoulzadegan (1989) and Caparroy et al. (1998) have shown that C. typicus feeds actively on the protozoan Strombidium sulcatum, but there is no data in the literature describing the effects of its ingestion on the development rate and egg production of this copepod.

The present study therefore investigated the effect of food quality on the development of the copepod Centropages typicus over 1 complete generation, including egg production of the subsequent generation. Different cohorts were reared on specific diets of pure algae or

Table 1. Initial densties of Centropages typicus and concentrations of its food sources in the mesocosms

\begin{tabular}{|lclc|}
\hline Cohort & $\begin{array}{c}\text { Initial Copepodite I } \\
\text { density (ind. }{ }^{-1} \text { ) }\end{array}$ & \multicolumn{1}{c|}{ Diet } & Cells ml ${ }^{-1}$ \\
\hline Nauplii & & Isochrysis galbana & 100000 \\
Subcohorts & & & \\
A & 580 & Hymenomonas elongata & 5000 \\
B & 440 & Thalassiosira weissflogii & 5000 \\
C & 590 & Strombidium sulcatum & 45 \\
D & 820 & H. elongata + S. sulcatum & $5000+45$ \\
E & 400 & T. weissflogii + S. sulcatum & $5000+45$ \\
\hline
\end{tabular}

pure ciliate, or mixtures of both food types, in order to examine the effect of dietary diversity on growth, development, egg production and hatching success.

\section{MATERIALS AND METHODS}

Cultures and experimental set up. Algal cultures were grown in Guillard F/2 medium and exposed to the same light:dark cycle (12:12 h) as Centropages typicus. Bacterial suspensions used to feed the protozoan Strombidium sulcatum were cultured by adding $20 \mathrm{~g}$ of protease peptone and $2.5 \mathrm{~g}$ of yeast extract to $1 \mathrm{l}$ of filtered seawater $(0.22 \mu \mathrm{m})$. The algae and protozoan used were in the exponential growth phase $(7$ to $10 \mathrm{~d}$ for the algae, 3 to $4 \mathrm{~d}$ for protozoa). Cell sizes of the food items were measured under a microscope. Ten $\mathrm{ml}$ of cultures were filtered through combusted GF/F filters and measured with a Model 10 fluorometer (Turner Designs, Sunnyvale, CA) for chl a or a CHN analyzer (LEICO 900) for C and N content.

Zooplankton were collected at the entrance of Villefranche Bay (Mediterranean Sea) with a WP2 net at $100 \mathrm{~m}$ depth. Three hundred to 400 adult female Centropages typicus Krøyer were placed in a 51 plexiglas cylinder (200 $\mu \mathrm{m}$ bottom mesh) filled with filtered seawater containing Hymenomonas elongata (Haptophyceae) at a concentration of 5000 cells $\mathrm{ml}^{-1}$ at $15^{\circ} \mathrm{C}$. After $1 \mathrm{~d}$, the females were separated from the eggs. A concentration of 100000 cells $\mathrm{ml}^{-1}$ of Isochrysis galbana (Prymnesiophyceae) was offered as food during naupliar development. When the cohort reached the NVI/CI stages, it was divided into 5 sub-cohorts which were fed different food sources: (1) the haptophyceaen $H$. elongata, (2) the diatom Thalassiosira weissflogii, (3) the ciliate Strombidium sulcatum, (4) H. elongata $+S$. sulcatum, or (5) T. weissflogii $+S$. sulcatum. Table 1 presents the food concentrations and the initial copepod concentrations for the different cohorts studied. The cultures were sampled and mixed daily.

Food concentrations were chosen based on previous studies on Centropages typicus such that Hymenomonas elongata and Strombidium sulcatum were offered at near optimal concentrations to achieve maximal ingestion rates (Bonnet 1998, Caparroy 1998, Caparroy et al. 1998), and Thalassiosira weissflogii was offered at concentrations that would ensure maximal egg production rates (Smith \& Lane 1985). The subcohorts were sampled daily, and food concentrations were adjusted as necessary. Optimum algal concentrations 
were used in the single diet to achieve a maximum ingestion response. In mixed cultures, the addition of phytoplankton cells to $S$. sulcatum yields a ciliate carbon/phytoplankton chl a ratio of 3.6, a value similar to those found by Dolan \& Marrasé (1995) in the Mediterranean Sea. All sub-cohorts Centropages typicus were reared at $15^{\circ} \mathrm{C}$ under a $12: 12 \mathrm{~h}$ light:dark cycle.

Development and growth. Sample volume varied daily as a function of the population density of a cohort, so that the first sample represented $1 \%$ of the total volume (at the beginning) and the last sample represented $4 \%$ of the final volume (4.5 l) and consisted of 20 to 40 individuals. The samples were fixed and preserved in $4 \%$ formalin, and stage distribution determined under a binocular microscope. Stage durations were calculated using the median development time of stage frequencies defined as the time for $50 \%$ of the cohort to moult to the next stage (Klekowski \& Duncan 1975, Landry 1975). Only the CV and CVI stages were considered for determining the male to female ratio, and the final ratio is an average of daily values. Mortality rates were calculated for the whole copepodid development (CI to CVI) for each food source as well as for the nauplii lifespan (egg to NVI) by fitting decreasing exponential curves to the data.

To measure body length of each stage, formalin samples from successive dates were pooled to obtain 30 individuals for each stage. Cephalothorax length of copepodids and total length of nauplii were measured. All individuals were subsequently washed with ammonium formiate $\left(68 \mathrm{~g} \mathrm{l}^{-1}\right)$, dried at $70^{\circ} \mathrm{C}$ for $72 \mathrm{~h}$, and finally weighed with a microbalance. Length-weight relationships were determined for each diet $( \pm 1 \mu \mathrm{g})$. Copepod dry weights were converted to carbon assuming that carbon represents $37.6 \%$ of the dry weight (Gorsky et al. 1988). When $50 \%$ of the population had reached the CVI stage, the cultures were discontinued.

Ingestion rates from grazing experiments rate. Ingestion experiments were made on NVI and CIII stages: NVI from the initial cohort reared on Isochrysis galbana (8 groups of 30 individuals) and CIII from the sub-cohorts reared on different food sources (3 groups of 50 individuals taken from each cohort) were incubated in bottles of 125 and $1000 \mathrm{ml}$, respectively, under the same food conditions as the cohorts from which they were taken. The bottles with copepods as well as those without (controls) were fixed on a Ferris wheel and gently rotated $(1.5 \mathrm{rpm})$ for $24 \mathrm{~h}$ in the same conditions. After $24 \mathrm{~h}$, samples were taken to determine cells concentrations in the bottles, and mortality of the copepods was estimated. Algal cells and the protozoan were preserved in $2 \%$ acid Lugol solution and counted with a Lemaur or Malassez cell under a microscope for the algae and with an inverted microscope after sedimentation in an Utermöhl chamber for the ciliate. Ingestion rates were calculated according to Frost (1972).

Egg production, egestion and egg viability. When $50 \%$ of a sub-cohort population had reached the adult stage, adult females $(<3 \mathrm{~d}$ old) were taken from the sub-cohort, divided into 4 groups of 10 individuals each and placed in $300 \mathrm{ml}$ beakers with a $200 \mu \mathrm{m}$ mesh filter on the bottom so that adults could not feed on their eggs. Three males were introduced to each beaker to ensure fertilisation. Copepods were fed with the same food source used during their development. The incubation medium was changed every day, and egg and faecal pellet number and female mortality were measured. At least 30 of the eggs produced each day were divided between a series of $10 \mathrm{ml}$ chambers, and their hatching success was observed until the nonhatched eggs were decomposing. The experiments were run until all the females had died.

Differences among experiments on ingestion, egg and faecal pellet production, hatching success, sex ratio and mortality were statistically tested using an ANOVA followed by a Tukey's HSD test. For non-homogeneous variance, the non-parametric KolmogorovSmirnov test was used.

\section{RESULTS}

\section{Characteristics of diets offered}

The C, N and chl a content of the food types are presented in Table 2. For Centropages typicus nauplii, a small $(6 \mu \mathrm{m})$ alga Isochrysis galbana was used, whereas for the copepodid stages, 2 further algae Hymenomonas elongata and Thalassiosira weissflogii

Table 2. Equivalent spherical diameter (ESD), carbon, nitrogen and chl a content of cells offered as food source to Centropages typicus. Strombidium sulcatum length includes hair length. Data are means \pm SD

\begin{tabular}{|c|c|c|c|c|c|c|}
\hline Diet & $\mathrm{ESD}(\mu \mathrm{m})$ & $\mathrm{C}\left(\mathrm{pg} \mathrm{cell} \mathrm{C}^{-1}\right)$ & $\mathrm{N}\left(\right.$ pg cell $\left.{ }^{-1}\right)$ & $\mathrm{C} / \mathrm{N}$ & $\operatorname{chl}\left(\right.$ pg cell $\left.{ }^{-1}\right)$ & $\mathrm{C} / \mathrm{chl} a$ \\
\hline Isochrysis galbana & $6.00 \pm 1.06$ & $15.39 \pm 1.12$ & $1.66 \pm 0.09$ & 9.27 & $0.243 \pm 0.002$ & 64.13 \\
\hline Hymenomonas elongata & $13.00 \pm 2.55$ & $286.55 \pm 13.24$ & $17.62 \pm 0.72$ & 16.26 & $2.440 \pm 0.034$ & 117.44 \\
\hline Thalassiosira weissflogii & $11.77 \pm 1.81$ & $159.68 \pm 4.36$ & $29.53 \pm 1.06$ & 5.41 & $2.002 \pm 0.130$ & 79.84 \\
\hline Strombidium sulcatum & $86.41 \pm 12.23$ & $4267.22 \pm 257.51$ & $977.5 \pm 50.39$ & 4.36 & - & - \\
\hline
\end{tabular}


Table 3. Initial cell concentrations and $\mathrm{C}, \mathrm{N}$ and chl a contents of diets fed to Centropages typicus

\begin{tabular}{|c|c|c|c|c|c|}
\hline Cohort & Diet & cells $\mathrm{ml}^{-1}$ & $\mu g \mathrm{Cl}^{-1}$ & $\mu g \mathrm{~N}^{-1}$ & $\mu g \operatorname{chl} a 1^{-1}$ \\
\hline Nauplii & Isochrysis galbana & 100000 & 1539 & 166 & 24.3 \\
\hline \multicolumn{6}{|c|}{ Subcohorts } \\
\hline $\mathrm{A}$ & Hymenomonas elongata & 5000 & 1433 & 88.1 & 12.2 \\
\hline B & Thalassiosira weissflogii & 5000 & 799 & 147.6 & 10 \\
\hline $\mathrm{C}$ & Strombidium sulcatum & 45 & 192 & 44 & - \\
\hline $\mathrm{D}$ & H. elongata $+S$. sulcatum & $5000+45$ & $1433+192$ & $166+44$ & 12.2 \\
\hline $\mathrm{E}$ & T. weissflogii $+S$. sulcatum & $5000+45$ & $799+192$ & $147.6+44$ & 10 \\
\hline
\end{tabular}

of the same size $(12 \mu \mathrm{m})$ and with the same chl a content $\left(\sim 2 \mathrm{pg} \mathrm{cell}^{-1}\right)$ were offered. $H$. elongata has a very high $\mathrm{C} / \mathrm{N}$ ratio compared to $T$. weissflogii. The ciliate Strombidium sulcatum, the largest prey $(85 \mu \mathrm{m})$, has a low $\mathrm{C} / \mathrm{N}$ ratio compared to the algae. These characteristics of the food sources enabled us to estimate the concentrations offered in terms of $\mathrm{C}, \mathrm{N}$ and chl a (Table 3). In general, the concentrations were very

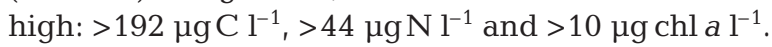

\section{Egg and naupliar development}

Fifty percent of the eggs had hatched after $33.6 \mathrm{~h}$, and $95 \%$ after $72 \mathrm{~h}$. A few stragglers remained for up to $5 \mathrm{~d}$ (Fig. 1, Table 4). Development of nauplii fed Isochrysis galbana lasted for ca 12 d. During naupliar development, there was good synchronism in the moult of the whole population I. galbana. Only 5 to $10 \%$ stragglers were observed, and this ratio was stable and did not increase with time. The NI stage was short compared to the other naupliar stages, which are feeding stages, NIV was the longest naupliar stage (Fig. 1, Table 4).

\section{Copepodite development and adult sex ratio}

Single food sources induced different copepodite development rates. CIV and CV took up around $62 \%$ of the cumulative copepodid duration with Thalassiosira weissflogii as food source, $53 \%$ with Hymenomonas elongata, Strombidium sulcatum and H. elongata + S. sulcatum, T. weissflogii, and $44 \%$ with T. weissflogii $+S$. sulcatum. CV stage was the longest of the copepodid stages regardless of food type.

The combinations of Hymenomonas elongata + Strombidium sulcatum, or Thalassiosira weissflogii $+S$. sulcatum resulted in an intermediate stage duration compared to the development times with either food source alone. Stragglers were oserved for the CI and CII stages in the $H$. elongata cohort and for the CI instar in the populations fed $H$. elongata $+S$. sulcatum or $T$. weissflogii (Fig.1).

Sex ratios are also shown in Table 4 . Diet had a significant effect on sex ratio (ANOVA: calculated $F_{\mathrm{C}}=$ 2.57 ; theoretical $\left.F_{\text {theo }(4 ; 63 ; 5 \%)}=2.52 ; \mathrm{p}<0.05\right)$. The culture reared on Thalassiosira weissflogii had a particularly low sex ratio (females/males $=0.535$ ) (Tukey's HSD: $\mathrm{p}<0.05$ ), whereas the other diets produced a more equal balance of females and males.

\section{Mortality rates}

The mean mortality rate from eggs to NVI was estimated at $0.01 \mathrm{~d}^{-1}$. Mean copepodid mortality rates were equal to 0.09 and $0.15 \mathrm{~d}^{-1}$, in cultures with Thalassiosira weissflogii + Strombidium sulcatum and

Table 4. Centropages typicus. Duration of development stages at $15^{\circ} \mathrm{C}$ as a function of food source. Also shown are mortality rates and sex ratios (Female CV $+\mathrm{CVI}) /($ Male $\mathrm{CV}+\mathrm{CVI}$ ) of cohorts fed different food sources (mean $\pm \mathrm{SD}$ )

\begin{tabular}{|c|c|c|c|c|c|c|c|c|c|c|}
\hline \multirow[t]{2}{*}{ Diet } & \multicolumn{7}{|c|}{ Development stage duration (d) } & \multirow{2}{*}{$\begin{array}{c}\begin{array}{c}\text { Cumulative } \\
\text { duration (d) }\end{array} \\
\text { Egg-N6 }\end{array}$} & \multirow{2}{*}{$\begin{array}{l}\text { Mortality } \\
\text { rate }\left(\mathrm{d}^{-1}\right)\end{array}$} & \multirow[t]{2}{*}{ Sex ratio } \\
\hline & Egg & N1 & N2 & N3 & N4 & N5 & N6 & & & \\
\hline \multirow[t]{2}{*}{ Isochrysis galbana } & 1.40 & 0.95 & 1.90 & 1.05 & 2.75 & 1.65 & 1.85 & 11.55 & 0.0106 & \\
\hline & CI & CII & CIII & CIV & CV & & & $\mathrm{CI}-\mathrm{CV}$ & & \\
\hline Hymenomonas elongata & 0.83 & 1.93 & 4.07 & 2.71 & 4.79 & & & 14.33 & 0.1086 & $0.943 \pm 0.562$ \\
\hline Thalassiosira weissflogii & 0.90 & 3.00 & 5.50 & 7.13 & 8.25 & & & 24.78 & 0.1173 & $0.535 \pm 0.282$ \\
\hline Strombidium sulcatum & 0.85 & 2.09 & 4.55 & 3.91 & 5.00 & & & 16.40 & 0.1676 & $0.843 \pm 0.567$ \\
\hline H. elongata $+S$. sulcatum & 0.88 & 2.15 & 4.56 & 4.09 & 5.00 & & & 16.68 & 0.1458 & $1.107 \pm 0.758$ \\
\hline T. weissflogii $+S$. sulcatum & 1.20 & 3.90 & 4.90 & 2.30 & 5.80 & & & 18.10 & 0.0861 & $1.054 \pm 0.506$ \\
\hline
\end{tabular}




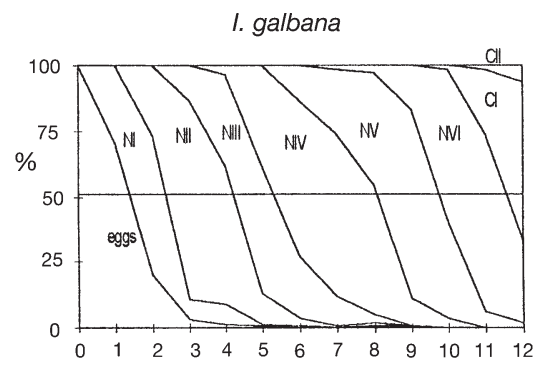

H. elongata

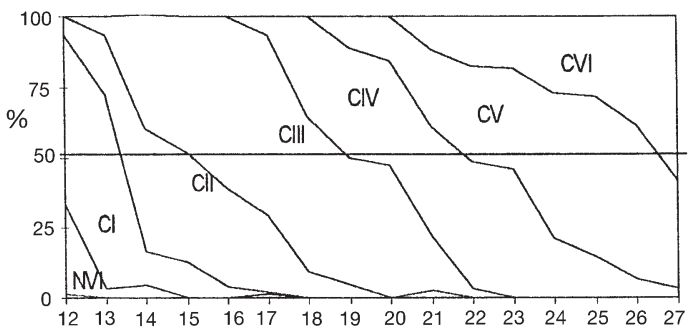

H. elongata + S. sulcatum

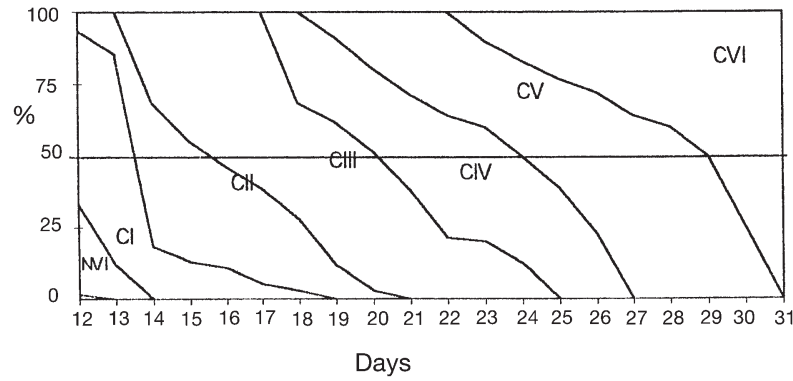

S. sulcatum

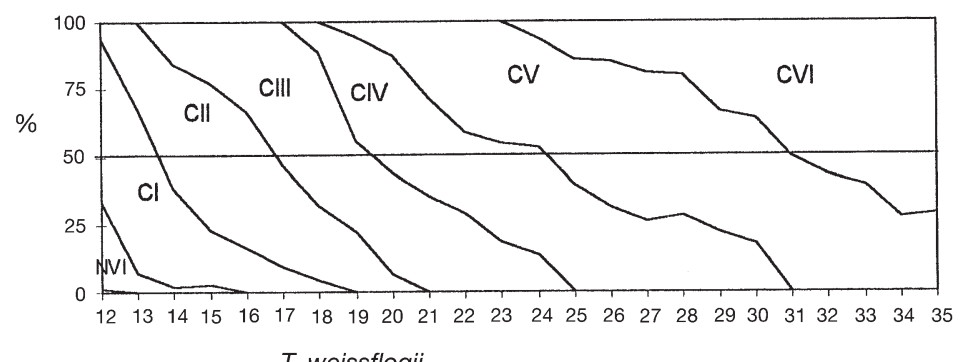

T. weissflogii

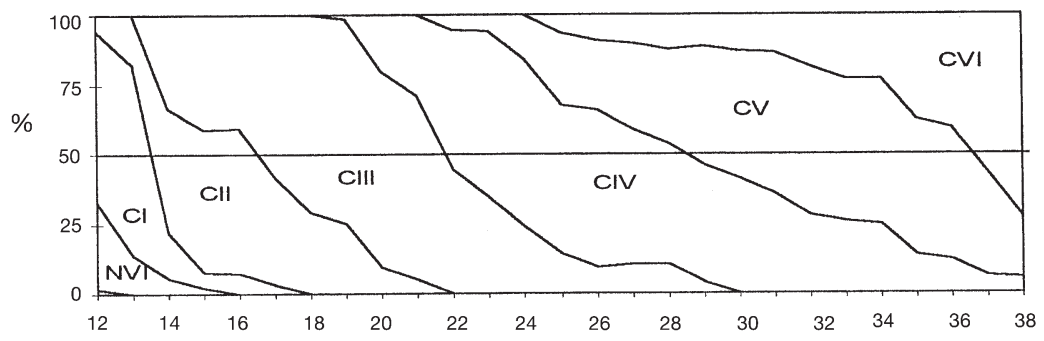

T. weissflogii + S. sulcatum

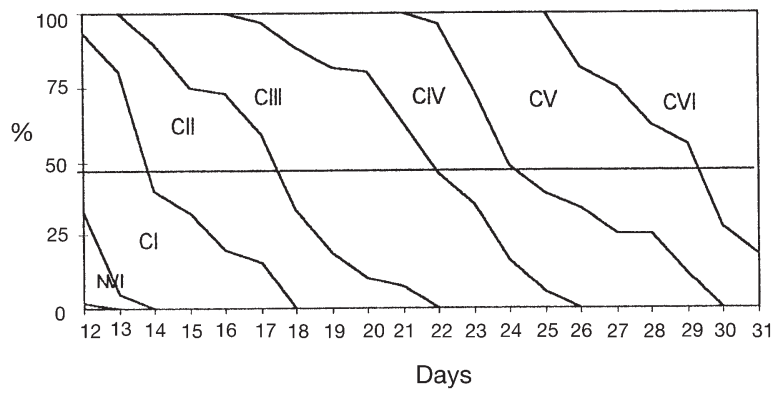

Days

Fig. 1. Centropages typicus. Distribution of development stages (\%) as a function of food type. Full specific names are given in Table 1

Hymenomonas elongata + S. sulcatum diets, respectively. H. elongata, T. weissflogii and S. sulcatum induced mean copepodid mortality rates of $0.11,0.12$ and $0.17 \mathrm{~d}^{-1}$, respectively (Table 4 ). There was no significant influence of the diets offered on copepodid mortality rates (ANOVA: $F_{\mathrm{C}}=5.36 ; F_{\text {theo }(4 ; 17 ; 5 \%)}=8.91$ ). The mortality rates included mortality due to daily sampling ( 1 to $4 \%$ of the population), and NVI and CIII individuals used for ingestion experiments.

\section{Growth}

Diet had significant effects on the cephalothorax length of CI (ANOVA: $\left.F_{\mathrm{C}}=8.58 ; F_{\text {theo }(4 ; 139 ; 0.001)}=4.90\right)$, CII (ANOVA: $F_{\mathrm{C}}=6.95 ; \quad F_{\text {theo }(4 ; 145 ; 0.001)}=4.89$ ), CIII (ANOVA: $\left.F_{\mathrm{C}}=4.45 ; F_{\text {theo }(4 ; 145 ; 0.01)}=3.45\right), \mathrm{CV}$ male (ANOVA: $F_{\mathrm{c}}=6.37 ; F_{\text {theo }(4 ; 132 ; 0.001)}=4.91$ ) and female (ANOVA: $\left.F_{\mathrm{c}}=6.18 ; F_{\text {theo }(4 ; 117 ; 0.001)}=4.96\right)$ stages. Dry weight increased exponentially over time with all diets. Specific growth rate, $g$ (slopes in Table 5), was significantly lower with the Thalassiosira weissflogii $\left(4.5 \% \mathrm{~d}^{-1}\right)$ diet than with the others ( 9 to $15 \%$ body wt $\mathrm{d}^{-1}$ ) diets. Whatever the diet offered, the dry weights measured in this study are among the highest in the lit-

Table 5. Centropages typicus. Linear model relating ln(mean dry weight) ( $\mu \mathrm{g}$ ind $\left.{ }^{-1}\right)$ to time. Specific growth rate $(g)$ given by slope. All regressions are significant at $\mathrm{p}<0.05$. Slopes did not differ significantly $(p>0.05)$ from each other except for the T. weissflogii treatment

\begin{tabular}{|c|c|c|c|}
\hline $\begin{array}{l}\text { Development } \\
\text { stage }\end{array}$ & Diet & Slope & $\mathrm{R}$ \\
\hline NIII-NVI & Isochrysis galbana & 0.0966 & 0.99 \\
\hline $\mathrm{CI}-\mathrm{CV}$ & Hymenomonas elongata & 0.1480 & 0.93 \\
\hline CI-CV & Thalassiosira weissflogii & 0.0446 & 0.85 \\
\hline CI-CV & Strombidium sulcatum & 0.1262 & 0.79 \\
\hline CI-CV & H. elongata $+S$. sulcatum & 0.1249 & 0.97 \\
\hline CI-CV & $T$. weissflogii $+S$. sulcatum & 0.0932 & 0.79 \\
\hline
\end{tabular}


Table 6. Centropages typicus. Summary of length and dry weight of the various development stages. -: no data. Full specific names as in Table 5

\begin{tabular}{|c|c|c|c|c|c|}
\hline Stage & $\mathrm{T}\left({ }^{\circ} \mathrm{C}\right)$ & Diet & Dry weight $(\mu g)$ & $\begin{array}{l}\text { Cephalothorax } \\
\text { length }(\mu \mathrm{m})\end{array}$ & Source \\
\hline CVI female & - & In situ patchiness & $39.9^{\mathrm{a}}$ & - & Dagg \& Grill (1980) \\
\hline CVI female & 8 & In situ patchiness & $50.8 \pm 0.6$ & $2030^{\mathrm{d}}$ & Smith \& Lane (1985) \\
\hline CVI female & 11 & In situ patchiness & $43.3 \pm 3.0$ & $1920^{\mathrm{d}}$ & Smith \& Lane (1985) \\
\hline CVI female & 13 & In situ patchiness & $47.0 \pm 2.3$ & $1880^{\mathrm{d}}$ & Smith \& Lane (1985) \\
\hline CVI female & 20 & In situ patchiness & $23.2 \pm 0.5$ & $1640^{\mathrm{d}}$ & Smith \& Lane (1985) \\
\hline CVI female & - & In situ patchiness & $\begin{array}{l}47.3 \text { (ranging } \\
\text { from } 10 \text { to } 98 \text { ) }\end{array}$ & $\begin{array}{c}\text { ranging } \\
\text { from } 976 \text { to } 1260\end{array}$ & Razouls \& Razouls (1976) \\
\hline CVI female & 15 & 0.5 to $6 \mu \mathrm{g} \mathrm{chl} \mathrm{a} \mathrm{l}^{-1}$ & $16.25-28.75^{\mathrm{a}, \mathrm{b}}$ & $1020-1120$ & Davis \& Alatalo (1992) \\
\hline CVI & $16.5-17.5$ & Excess of Oxyrrhis marina & $26^{\mathrm{c}}$ & - & Fryd et al. (1991) \\
\hline CVI female & 15 & T. weissflogii + S. sulcatum & 66.45 & 1119 & This study \\
\hline CVI female & 15 & $H$. elongata $+S$. sulcatum & 55.14 & 1093 & This study \\
\hline CVI female & 15 & S. sulcatum & 52.67 & 1098 & This study \\
\hline CVI female & 15 & H. elongata & 31.40 & 1095 & This study \\
\hline CVI female & 15 & T. weissflogii & 29.14 & 1068 & This study \\
\hline CVI male & - & In situ patchiness & $\begin{array}{l}47.1 \text { (ranging } \\
\text { from } 10 \text { to } 110 \text { ) }\end{array}$ & $\begin{array}{l}\text { ranging from } \\
961 \text { to } 1188\end{array}$ & Razouls \& Razouls (1976) \\
\hline CVI male & 15 & 0.5 to $6 \mu \mathrm{g} \mathrm{chl} \mathrm{a} \mathrm{l}^{-1}$ & $13.75-21.25^{\mathrm{a}, \mathrm{b}}$ & $1000-1090$ & Davis \& Alatalo (1992) \\
\hline CVI male & 15 & H. elongata $+S$. sulcatum & 57.18 & 1051 & This study \\
\hline CVI male & 15 & T. weissflogii + S. sulcatum & 45.42 & 1069 & This study \\
\hline CVI male & 15 & H. elongata & 42.26 & 1037 & This study \\
\hline CVI male & 15 & S. sulcatum & 39.33 & 1039 & This study \\
\hline CVI male & 15 & T. weissflogii & 22.37 & 1017 & This study \\
\hline $\mathrm{CV}$ female & 15 & 0.5 to $6 \mu \mathrm{g} \mathrm{chl} \mathrm{a} \mathrm{l}^{-1}$ & $7.5-8.75^{\mathrm{a}, \mathrm{b}}$ & $880-910$ & Davis \& Alatalo (1992) \\
\hline CV female & 15 & H. elongata $+S$. sulcatum & 44.81 & 898 & This study \\
\hline CV female & 15 & H. elongata & 34.68 & 879 & This study \\
\hline CV female & 15 & T. weissflogii + S. sulcatum & 32.99 & 880 & This study \\
\hline CV female & 15 & S. sulcatum & 31.08 & 839 & This study \\
\hline CV female & 15 & T. weissflogii & 15.76 & 832 & This study \\
\hline CV male & 15 & 0.5 to $6 \mu \mathrm{gchl} a \mathrm{l}^{-1}$ & $6.75-10^{\mathrm{a}, \mathrm{b}}$ & $840-890$ & Davis \& Alatalo (1992) \\
\hline $\mathrm{CV}$ & $16.5-17.5$ & Excess of Oxyrrhis marina & $16^{\mathrm{c}}$ & - & Fryd et al. (1991) \\
\hline CV male & 15 & H. elongata $+S$. sulcatum & 33.63 & 874 & This study \\
\hline CV male & 15 & H. elongata & 28.72 & 883 & This study \\
\hline CV male & 15 & T. weissflogii + S. sulcatum & 25.26 & 866 & This study \\
\hline CV male & 15 & S. sulcatum & 21.70 & 829 & This study \\
\hline CV male & 15 & T. weissflogii & 13.62 & 817 & This study \\
\hline CIV & 15 & 0.5 to $6 \mu \mathrm{gchl} a \mathrm{l}^{-1}$ & $2.5-3.75^{a, b}$ & $600-700$ & Davis \& Alatalo (1992) \\
\hline CIV & $16.5-17.5$ & Excess of Oxyrrhis marina & $7.8^{\mathrm{c}}$ & - & Fryd et al. (1991) \\
\hline CIV & 15 & S. sulcatum & 30.11 & 684 & This study \\
\hline CIV & 15 & T. weissflogii + S. sulcatum & 30.06 & 665 & This study \\
\hline CIV & 15 & H. elongata $+S$. sulcatum & 21.73 & 676 & This study \\
\hline CIV & 15 & T. weissflogii & 13.29 & 665 & This study \\
\hline CIV & 15 & H. elongata & 11.32 & 696 & This study \\
\hline CIII & 15 & 0.5 to $6 \mu \mathrm{gchl} a \mathrm{l}^{-1}$ & $2.5^{\mathrm{a}, \mathrm{b}}$ & $500-530$ & Davis \& Alatalo (1992) \\
\hline CIII & $16.5-17.5$ & Excess of Oxyrrhis marina & $4.2^{\mathrm{c}}$ & - & Fryd et al. (1991) \\
\hline CIII & 15 & $T$. weissflogii $+S$. sulcatum & 24.50 & 519 & This study \\
\hline CIII & 15 & S. sulcatum & 18.58 & 500 & This study \\
\hline CIII & 15 & H. elongata $+S$. sulcatum & 14.85 & 489 & This study \\
\hline CIII & 15 & T. weissflogii & 10.57 & 528 & This study \\
\hline CIII & 15 & H. elongata & 8.07 & 529 & This study \\
\hline CII & 15 & 0.5 to $6 \mu \mathrm{gchl} a \mathrm{l}^{-1}$ & $1.25-1.75^{\mathrm{a}, \mathrm{b}}$ & $400-420$ & Davis \& Alatalo (1992) \\
\hline CII & $16.5-17.5$ & Excess of Oxyrrhis marina & $2.4^{\mathrm{c}}$ & - & Fryd et al. (1991) \\
\hline CII & 15 & T. weissflogii + S. sulcatum & 15.00 & 402 & This study \\
\hline CII & 15 & S. sulcatum & 8.12 & 390 & This study \\
\hline CII & 15 & T. weissflogii & 7.67 & 428 & This study \\
\hline CII & 15 & H. elongata $+S$. sulcatum & 7.12 & 376 & This study \\
\hline CII & 15 & H. elongata & 5.60 & 407 & This study \\
\hline
\end{tabular}


Table 6 (continued)

\begin{tabular}{|c|c|c|c|c|c|}
\hline Stage & $\mathrm{T}\left({ }^{\circ} \mathrm{C}\right)$ & Diet & Dry weight $(\mu g)$ & $\begin{array}{l}\text { Cephalothorax } \\
\text { length }(\mu \mathrm{m})\end{array}$ & Source \\
\hline $\mathrm{CI}$ & 15 & 0.5 to $6 \mu \mathrm{g} \mathrm{chl} \mathrm{a} \mathrm{l^{-1 }}$ & $0.75^{a, b}$ & $300-320$ & Davis \& Alatalo (1992) \\
\hline $\mathrm{CI}$ & $16.5-17.5$ & Excess of Oxyrrhis marina & $1.4^{\mathrm{c}}$ & - & Fryd et al. (1991) \\
\hline $\mathrm{CI}$ & 15 & H. elongata $+S$. sulcatum & 7.77 & 323 & This study \\
\hline $\mathrm{CI}$ & 15 & T. weissflogii + S. sulcatum & 6.93 & 329 & This study \\
\hline $\mathrm{CI}$ & 15 & T. weissflogii & 5.58 & 353 & This study \\
\hline $\mathrm{CI}$ & 15 & H. elongata & 5.46 & 341 & This study \\
\hline $\mathrm{CI}$ & 15 & S. sulcatum & 4.91 & 320 & This study \\
\hline NVI & $16.5-17.5$ & Excess of Rhodomonos baltica & $1.05^{\mathrm{c}}$ & & Fryd et al. (1991) \\
\hline NVI & 15 & I. galbana & 3.31 & $277^{\mathrm{d}}$ & This study \\
\hline NV & $16.5-17.5$ & Excess of Rhodomonos baltica & $0.70^{\mathrm{c}}$ & & Fryd et al. (1991) \\
\hline NV & 15 & I. galbana & 2.82 & $247^{\mathrm{d}}$ & This study \\
\hline NIV & $16.5-17.5$ & Excess of Rhodomonos baltica & $0.50^{\mathrm{c}}$ & - & Fryd et al. (1991) \\
\hline NIV & 15 & I. galbana & 2.27 & $212^{\mathrm{d}}$ & This study \\
\hline NIII & $16.5-17.5$ & Excess of Rhodomonos baltica & $0.35^{\mathrm{c}}$ & - & Fryd et al. (1991) \\
\hline NIII & 15 & I. galbana & 1.94 & $174^{\mathrm{d}}$ & This study \\
\hline NII & $16.5-17.5$ & Excess of Rhodomonos baltica & $0.22^{\mathrm{c}}$ & - & Fryd et al. (1991) \\
\hline NII & 15 & I. galbana & 1.61 & $129^{\mathrm{d}}$ & This study \\
\hline \multicolumn{6}{|c|}{$\begin{array}{l}\text { a Carbon values (cw, } \mu \mathrm{g}) \text { were converted to dry weights (DW) using ratio: cw/DW }=0.376 \text { (Gorsky et al. 1988) } \\
{ }^{\mathrm{b}} \text { For copepodites, with } L>0.4 \mathrm{~mm}, W(\mu \mathrm{g})=0.06 \exp (4.612 \mathrm{~L})\end{array}$} \\
\hline
\end{tabular}

erature for Centropages typicus development stages (Table 6). Length-weight relationships are shown in Fig. 2. The correlation coefficients between dry weight and cephalothorax length ranged between 0.926 and 0.988, with no significant difference among diets (ANCOVA: $F_{\mathrm{C}}=0.086 ; F_{\text {theo }(4 ; 2 ; 0.1 \%)}=199$ ).

\section{Ingestion rate}

For Stage NVI fed Isochrysis galbana, ingestion rate was $0.48 \pm 0.25 \mu \mathrm{g} \mathrm{C} \mathrm{gg}^{-1}$ copepod $\mathrm{C} \mathrm{d}^{-1}$. Ingestion rates of CIII (Figure 3 ) varied among diets (ANOVA: $\left.F_{\mathrm{C}}=10.72 ; F_{\text {theo }(4 ; 9 ; 0.005)}=7.96\right)$. Among the pure diets,

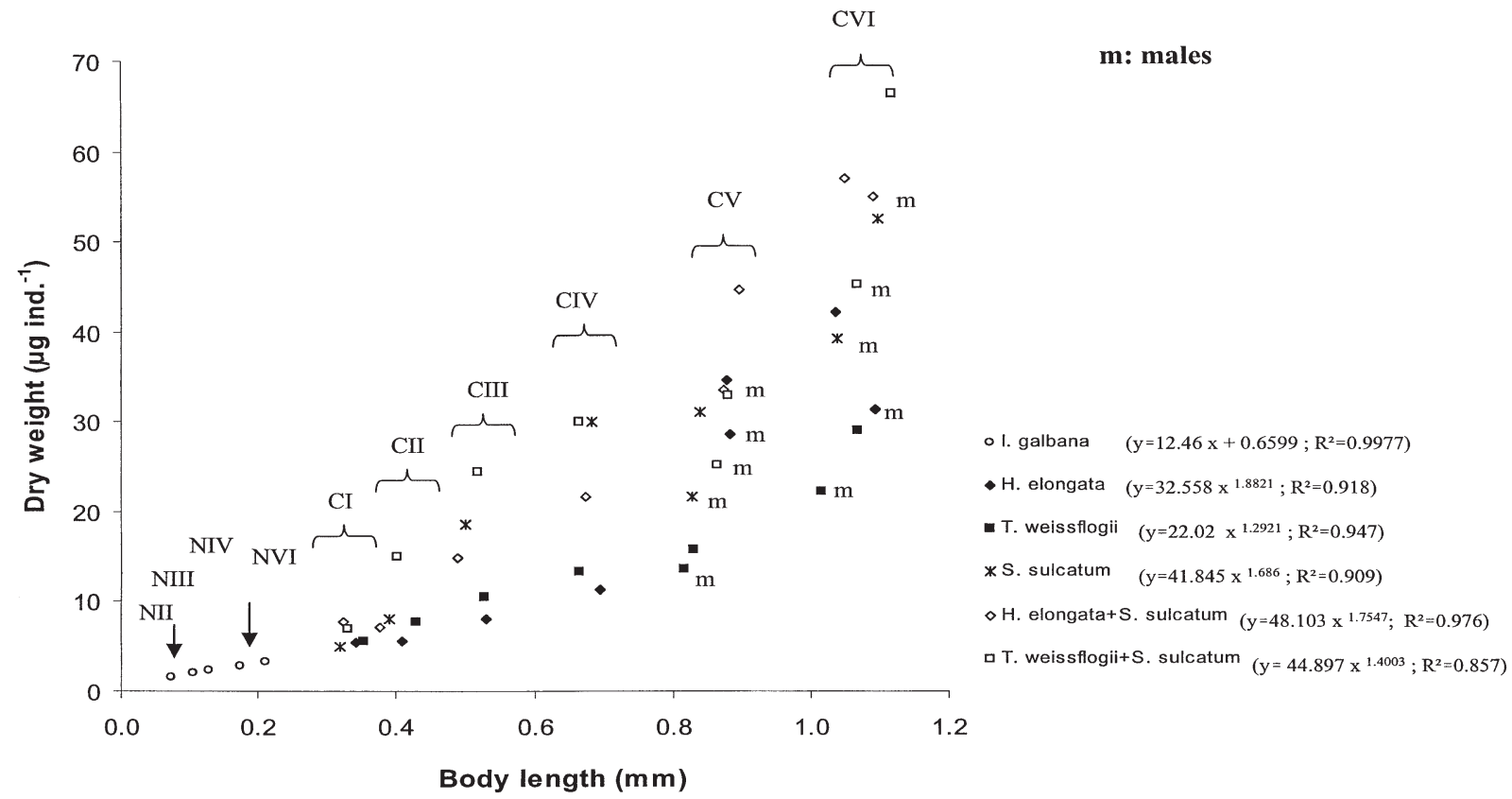

Fig. 2. Centropages typicus. Length-weight relationship of development stages of feed different diets 


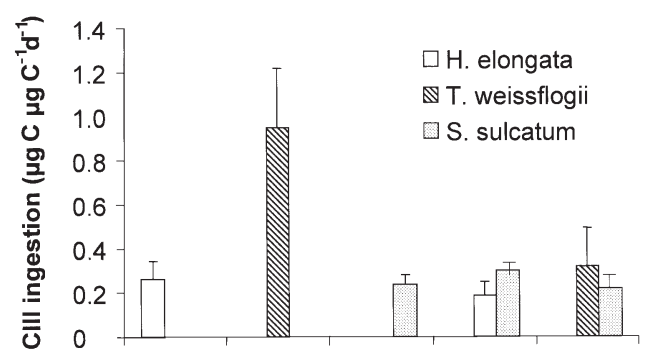

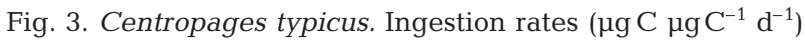
of CIII stages fed different diets. Values are means \pm SD

Thalassiosira weissflogii was ingested at the highest rate (Tukey's HSD: p < 0.05). For the mixed diets, a preliminary experiment showed negligible grazing impact of the ciliate Strombidium sulcatum on either Hymenomonas elongata or T. weissflogii. The total ingestion rates with the mixed diet were higher than the ingestion rates with each prey type offered alone, except for T. weissflogii. This means that CIII stages attained a higher ingestion rate in terms of carbon on mixed diets than when fed $H$. elongata or S. sulcatum alone, even though the concentrations offered were at saturation level.

Ingestion-dry weight ratios are presented in Table 7. The highest ingestion rate, $5.95 \mu \mathrm{g} \mathrm{C}$ ind.$^{-1} \mathrm{~d}^{-1}$ for Thalassiosira weissflogii + Strombidium sulcatum diet, was recorded for the heaviest individuals $(9.80 \mu \mathrm{g} \mathrm{C})$. Nevertheless, the highest ratio was displayed by copepods fed T. weissflogii. The ratio ingestion/dry weight varied strongly with the diet: ingestion of $T$. weissflogii represented $106 \%$ of the carbon weight for the CIII stage, whereas Hymenomonas elongata and S. sulcatum fed singly represented percentages lower than $30 \%$. For Isochrysis galbana in the NVI stage, the value was $48.5 \%$.

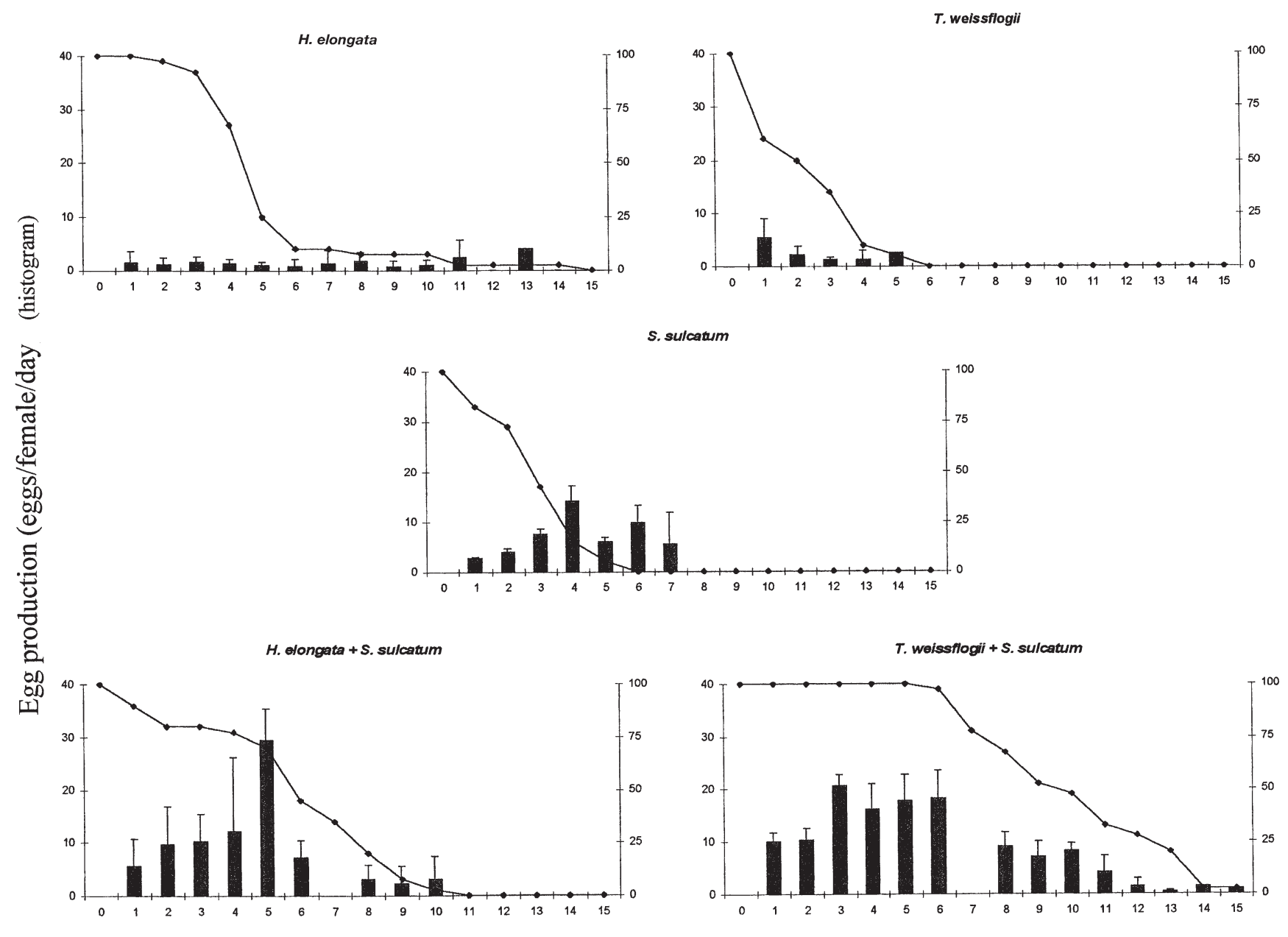

Time (d)

Fig. 4. Centropages typicus. Egg production rate and survival in the different cohorts (means + SD) 
Female survival, egg production and hatching success

Maximum egg production rate was observed from Days 3 to 5 for females in the cohorts reared on the algal plus ciliate diets, and corresponded to the point at which females began dying (Fig. 4). The rates increased by 3 - to 7 -fold over those of cohorts fed algae alone. There were no obvious trends over time in egg production rates for cohorts reared on pure algal diets. The rate was significantly dependent on the diet offered (ANOVA: $F_{\mathrm{C}}=5.81 ; F_{\text {theo }(4 ; 40 ; 0.001)}=4.37$ ).

When ciliates were included in the diet, female survival increased above those on pure algal or ciliate diets. The highest survival rates (in terms of longevity and percentage of females) were obtained for females reared on mixed (algae plus ciliate) diets. Indeed, $50 \%$ of the females died after 2 and $4.5 \mathrm{~d}$ on Thalassiosira weissflogii and Hymenomonas elongata diets respectively and after 5.85 and $9.5 \mathrm{~d}$ for T. weissflogii + Strombidium sulcatum and $H$. elongata $+S$. sulcatum diets.

On the fifth day, maximum egg production rate, which was on average 29 eggs female $\mathrm{f}^{-1}$, was reached by females grazing on Hymenomonas elongata + Strombidium sulcatum. Maximum fecundy (total number of eggs produced by a female during the observation time) was low on pure algal diets $(<20$ eggs female ${ }^{-1}$ ) (Tukey's HSD: $\left.\mathrm{p}<0.05\right)$, but reached 50, 82 and 125 eggs female ${ }^{-1}$ on $S$. sulcatum, H. elongata $+S$. sulcatum and Thalassiosira weissflogii $+S$. sulcatum diets, respectively (Tukey's HSD: p < 0.05).

No significant difference was observed between the hatching success of eggs from the different cultures (ANOVA: $F_{\mathrm{C}}=2.23 ; F_{\text {theo }(4 ; 39 ; 0.05)}=2.61$ ). For the ciliate diet, egg hatching success was $100 \%$ in $\leq 3$ d regardless of female age (Fig. 5). For the other diets, hatching success ranged from 50 to $100 \%$ for Hymenomonas elongata diet, 40 to $100 \%$ for Thalassiosira weissflogii alone, 90 to $100 \%$ for $H$. elongata + Strombidium sulcatum and 15 to $100 \%$ for T. weissflogii + S. sulcatum. Time to $50 \%$ hatching was also very variable, and in general was longer than $2 \mathrm{~d}$. There were no overall trends in the relationship between hatching success and diet or female survival.

\section{Faecal pellet production}

Faecal pellet production was not correlated with egg production for any food source nor with females' age (Fig. 6). No significant difference was noted between faecal pellet production of copepods on different diets
(ANOVA: $\left.F_{\mathrm{C}}=1.15 ; F_{\text {theo }(4 ; 45 ; 0.05)}=2.58\right)$. Nevertheless, the highest average faecal pellet production was observed for the diet containing Thalassiosira weissflogii mixed with Strombidium sulcatum ( 23 pellets ind. $\left.{ }^{-1} \mathrm{~d}^{-1}\right)$, whereas highest peak faecal pellet production was found for the Hymenomonas elongata + S. sulcatum diet $\left(\sim 30\right.$ pellets ind.$\left.^{-1} \mathrm{~d}^{-1}\right)$.

\section{DISCUSSION}

\section{Stage duration}

Stage durations of Centropages typicus in this study ranged from 31.79 to $44.63 \%$ for nauplii and from 55.37 to $68.21 \%$ for copepodids. Landry (1983) explained the long duration of the first feeding stage by the need to recuperate weight loss during the nonfeeding instars, and the duration of the CV instar by physiological changes in preparation for maturity.

The total development time varied from 25.9 to $36.4 \mathrm{~d}$ depending on diet (Table 4). These values are consistent (within any one diet) with development times of Centropages typicus at $15^{\circ} \mathrm{C}$ obtained for cultures by others authors: $25.82 \mathrm{~d}$ at 16000 cells ml $^{-1}$ of Hymenomonas elongata (Carlotti \& Nival 1992), $33.0 \mathrm{~d}$ at 4600 cells $\mathrm{ml}^{-1}$ of Thalassiosira weissflogii (Smith \& Lane 1987). In our mixed diets, T. weissflogii supplemented by the ciliate Strombidium sulcatum decreased the development time of the copepods compared to the pure T. weissflogi diet, but this was not the case for $H$. elongata, which proved to be a good diet for development without ciliate addition.

\section{Mortality rates}

Diet did not significantly affect copepodid mortality rates (ANOVA: Table 4). The values obtained herein comprised the mortality rate of organisms plus the loss to daily sampling which varied with volume sampled $\left(1 \% \mathrm{~d}^{-1}\right.$ at the beginning of the experiment, rising to 
A
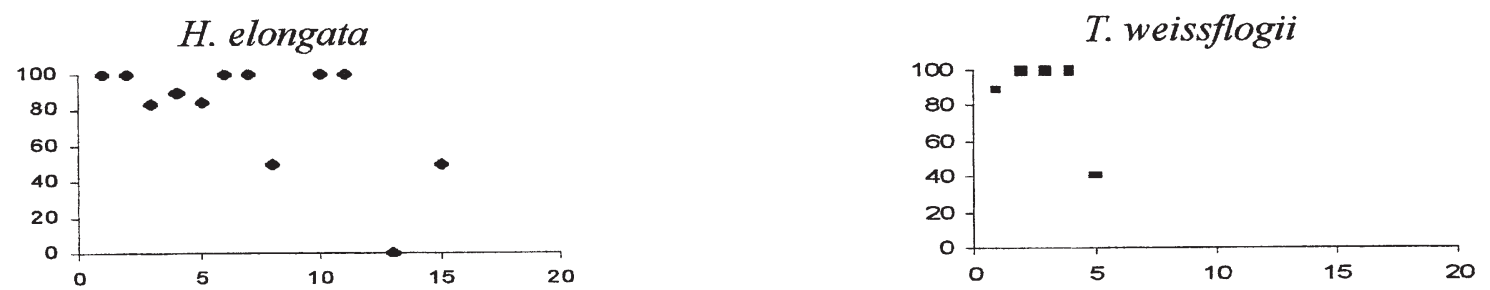

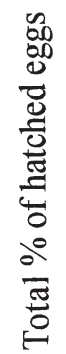

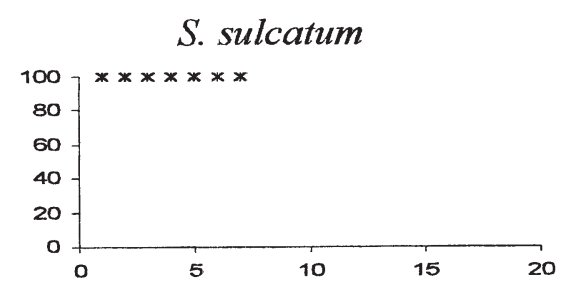

H. elongata $+S$. sulcatum

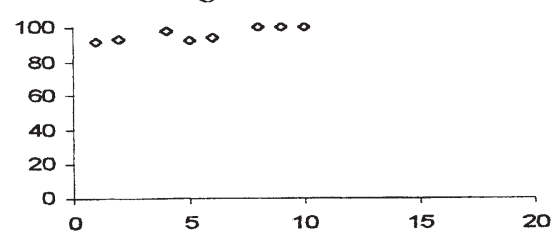

T. weissflogii + S. sulcatum

B

H. elongata

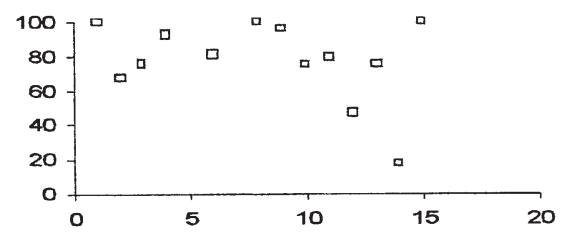

Female age (d)

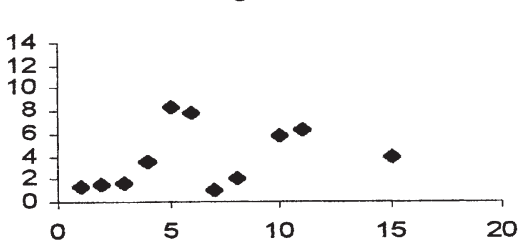

T. weissflogii

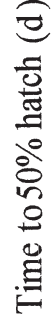

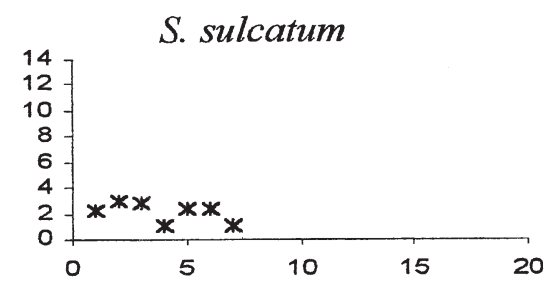

H. elongata + S. sulcatum

T. weissflogii + S. sulcatum
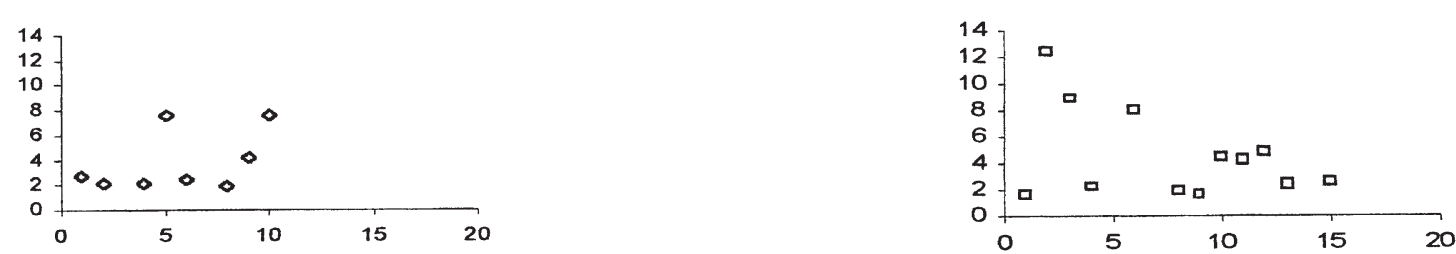

Female age (d)

Fig. 5. Centropages typicus. Total percentage of (A) hatched eggs and (B) time to $50 \%$ hatch, as a function of age of reproductive females and their diet 
H. elongata

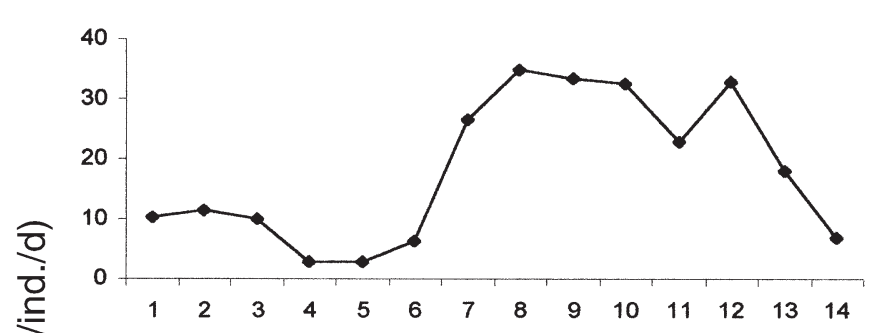

T. weissflogii

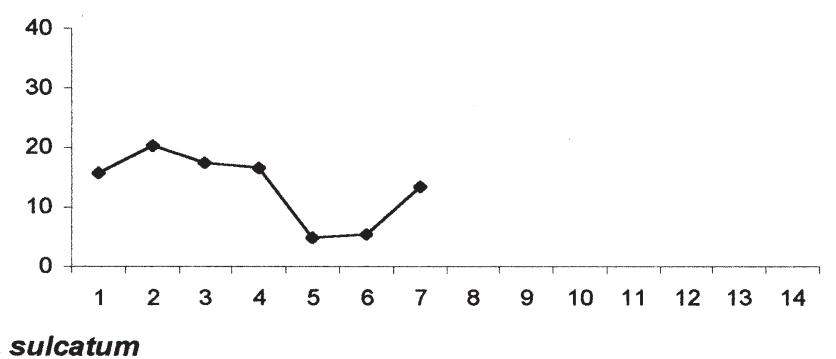

S. sulcatum

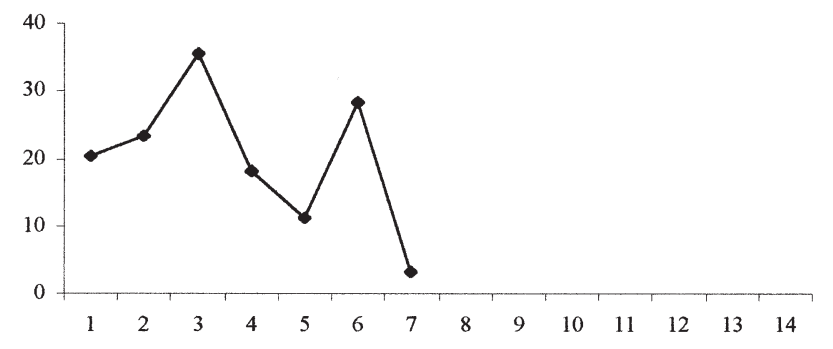

H. elongata + S. sulcatum

T. weissflogii + S. sulcatum
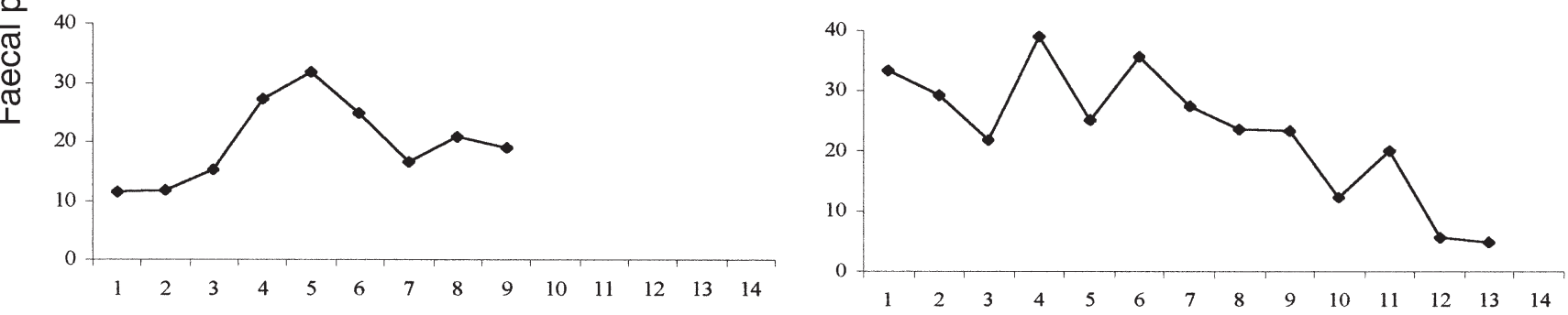

Female survival time (d)

Fig. 6. Centropages typicus. Faecal pellet production rate as a function of female survival time (d) for the different diets

$4 \% \mathrm{~d}^{-1}$ at the end of the experiment). These values are in the range of mortality rates obtained for small copepods such as Pseudocalanus newmani by Ohman \& Wood (1995, see their Fig. 3).

\section{Female longevity}

Survival of females reared on Thalassiosira weissflogii was particularly short ( 2 d), in agreement with observations by Ianora \& Poulet (1993) of wild female Temora stylifera: longevity was, on average, lower when $T$. stylifera were reared on the diatom $T$. rotula than on the dinoflagellate Prorocentrum minimum. The lifespan of female Centropages typicus fed Hymenomonas elongata was longer in the study of Carlotti et al. (1997) than in the present study. They report $50 \%$ female mortality at 15 and $20^{\circ} \mathrm{C}$ after 22.25 and $15.5 \mathrm{~d}$, respectively. The explanation for this difference may be methodological, since the females cho- sen for our experiments were not freshly moulted females, but females taken from mesocosms in which $50 \%$ of the population had reached the adult stage (i.e. $5 \mathrm{~d}$ after the appearance of first females). The results of the present study must therefore be considered to represent minimum values for longevity.

\section{Sex ratio}

Many studies have related sex ratio to various factors such as temperature, season and population density (Mauchline 1998). The impact of food quality on the sex ratio of copepod cohorts raised in the laboratory has been considered, but without reaching any clear conclusion. Results from a laboratory culture of Calanus helgolandicus suggested that both food concentration and phytoplankton species composition may be important in sex determination (Paffenhöffer 1970), but in a study by Arnott et al. (1986), neither food concentration 
nor food quality had an effect on the sex ratio of the calanoid copepod Gladioferens pectinatus. Our results show that Centropages typicus reared on Thalassiosira weissflogii skewed towards males; this is consistent with the rapid decrease of females in the egg production experiments with this diet (see Fig. 4). For the other diets, the sex ratio was close to 1 .

\section{Dry weight and length}

Length and weight of Centropages typicus have been reported to be dependent on temperature and food concentration (see Mauchline 1998 for review). As far as we know, our study is the first to consider the effect of food quality on size, weight and development time of C. typicus simultaneously.

Our results highlight 3 major points: (1) A significant impact of diet on weight, for each stage, the highest weights being 2 to 3 times higher than the lowest ones. Comparable weight differences within Centropages typicus adults have already been shown by Smith \& Lane (1985, their Table 2) in their laboratory study on egg production and development. (2) A significant (ANOVA) impact of diet on stage length for all instars except CIV and CVI. The correlation between body length and diet in a limited number of instars supports this hypothesis, since it suggests that the food offered was more suitable for some stages than for others. For example, algal diets induced the highest lengths for $\mathrm{CI}$, CII and CIII stages, whereas mixed diets led to longer CV males and females (Fig. 2). (3) No significant difference between the length-weight relationships established for each food source (Fig. 2). The reason why length-weight relationships do not appear to be correlated with food quality may be changes in food requirements as individuals develop from copepodids to adults. There was a large difference in dry weights within the same stage for the different diets as well as a strong overlapping of weight ranges of successive stages. For example, the difference in CIII weight between individuals fed Thalassiosira weissflogii and those fed different diets suggests that food quality affects growth rate (weight and length) more than development rate (stage duration). In a study of the effect of food quality on the development of Calanus helgolandicus nauplii, Rey et al. (2001) reported that the food source which results in the shortest development time is not the food source which achieves the highest weights. This result is supported by the present study, in which single diets of the algae Hymenomonas elongata and $T$. weissflogii both led to the lowest adult weights (Table 4; Fig. 2). Conversely, mixed diets induced the highest weights, and Strombidium sulcatum alone produced intermediate values.

\section{Ingestion rate}

Centropages typicus has been shown to feed well on both algae (Smith \& Lane 1985, 1987, Guerrero et al. 1997, Bonnet 1998, Caparroy 1998), and on the ciliate Strombidium sulcatum (Wiadnyana \& Rassoulzadegan 1989, Caparroy et al. 1998).

The specific ingestion rates of adult females fed an optimal concentration of Hymenomonas elongata (Bonnet 1998) and fed Strombidium sulcatum (Caparroy 1998) were both $0.4 \mathrm{~d}^{-1}$, a rate reported in other studies on Centropages typicus (see Mauchline 1998). In comparison, the specific ingestion rates of CIII fed the same food types (see Fig. 3) in the present study were around $0.27 \mathrm{~d}^{-1}$. Specific ingestion rates are usually presumed to decrease with increasing weight, and thus with increasing stage (Paffenhöfer 1971); this was not the case in our study. We therefore presume that our CIII stage was not fed at optimum concentrations. The specific ingestion rate of CIII on Thalassiosira weissflogii $\left(0.95 \mathrm{~d}^{-1}\right)$ does seem a realistic value, comparable to those obtained for the CIII stage of calanoid copepods (Mauchline 1998).

Kleppel (1993) showed that requirements vary, with food nutritional requirements changing ontogenetically through the copepodid to adult stages. Copepodite stages devote all resources to growth, whereas adults place greater priority on reproduction. Jónasdóttir et al. (1995) and Müller-Navarra (1995a) suggested that the polyunsaturated fatty acids, eicosapentaenoic acid (EPA) and docosahexaenoic acid (DHA), are essential compounds, which can limit zooplankton productivity. In general, EPA occurs in significant amounts in diatoms, whereas DHA is abundant in dinoflagellates (Klein Breteler et al. 1999). Indeed, sterol availability influences survival and egg production. Copepods rely on dietary sterols to meet their metabolic requirements, since they lack biosynthetic capacity to synthesize sterols; this could explain the high ingestion rate of CIII fed $T$. weissflogii in our study.

\section{Prey characteristics}

Prey size also influences ingestion rate (Berggreen et al. 1988, Hansen et al. 1994). Hansen et al. (1994) calculated that the predator/prey size ratio for optimal selectivity is $18 \pm 4$ for nauplii and $18 \pm 3$ for copepodites.

Applying these ratios to the nauplii and copepodite sizes in our experiments results in optimum selectivities of particles between 5.8 and $15.4 \mu \mathrm{m}$ and between 18.5 and $60.8 \mu \mathrm{m}$, respectively. The size of Isochrysis galbana (see Table 2) its within the opti- 
mum range for nauplii. The sizes of Thalassiosira weissflogii and Hymenomonas elongata are below the optimal range of copepodid and adult selectivity. Thus we conclude that only the largest cells in our cultures were available as food. This could explain why the optimal threshold lay at cell concentrations

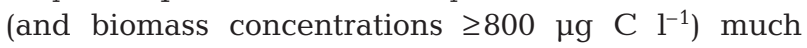
higher than the highest phytoplankton concentrations (in terms of carbon) observed in situ. Because of the large range of size changes in copepod stages, the size of prey offered is a major problem. Based on the Hansen et al. (1994) ratio, S. sulcatum is slightly too large for the copepodites; however, $S$. sulcatum is known to be successfully caught through ambush capture by Centropages typicus (Caparroy et al. 1998). Development times were not shorter when $S$. sulcatum was offered alone. However, compared with pure algal diets, mixed diets produced the highest final weights and sizes, probably because of the large prey spectrum available during development.

Selectivity could also involve cell carbon, nitrogen and protein composition. Cowles et al. (1988) have shown that copepods maximize the ingestion of nitrogen. In the present study, the 2 algae offered are of almost the same size (Hymenomonas elongata $13 \mu \mathrm{m}$; Thalassiosira weissflogii $\sim 12 \mu \mathrm{m}$ ); however $T$. weissflogii contains 1.68 times more nitrogen per cell than $H$. elongata. This could explain the high grazing rates on $T$. weissflogii, even though the copepods did not grow faster on this diet. The high $\mathrm{N}$ content and ingestion rate of $T$. weissflogii suggest that $\mathrm{N}$ was not a limiting nutrient for development and growth. The $\mathrm{C} / \mathrm{N}$ ratio demand of an animal depends on its own $\mathrm{C} / \mathrm{N}$ ratio (Urabe \& Watanabe 1992); however, in her in situ study on Centropages typicus, Razouls (1977) showed that $\mathrm{C} / \mathrm{N}$ ratios remained constant throughout the different stages, including the adult stages.

No correlation could be found in the present study between the $\mathrm{C} / \mathrm{N}$ ratio of the food offered and the rate of copepod development. For instance, whereas the $\mathrm{C} / \mathrm{N}$ ratios of both Hymenomonas elongata and Thalassiosira weissflogii were higher than that of Strombidium sulcatum, development time on the $S$. sulcatum diet lay between those of the 2 algal treatments. Therefore, the $\mathrm{C} / \mathrm{N}$ ratio does not appear to be an adequate indicator of the effect of food quality on development. Indeed, the $\mathrm{C} / \mathrm{N}$ ratio cannot be used to define the quality of a food source without first knowing the availability to and the efficiency of assimilation of carbon and nitrogen compounds by the copepods (Tang \& Dam 1999). Furthermore, recent studies have shown that growth and egg production in crustaceans are more dependent on dietary polyunsaturated fatty acids than on the elemental composition of the food (Jónasdóttir et al. 1995, Müller-Navarra 1995a,b).

\section{Egg production}

The effects of microzooplankton food on the fecundity of copepods have rarely been examined apart from the studies of Williamson \& Butler (1986) and Stoecker \& Egloff (1987). Stoecker \& Egloff have shown that inclusion of tintinnids in the diet of Acartia tonsa can increase egg production by $\sim 25 \%$ compared with a pure algal diet. In our study, addition of Strombidium sulcatum to the algal diet of Centropages typicus resulted in an increase in the egg production rate by $3-$ to 7 -fold, indicating a high food quality of the ciliate (Durbin et al. 1983, Stoecker \& Egloff 1987). Kleppel (1992) strongly suggested that the link between feeding and egg production may be what is eaten rather than how much. Heinle et al. (1977) pointed out that copepods, although showing some selectivity in grazing, tend to feed on a rather wide variety of food and proposed that protozoans are an important food source in the copepod diet as they enhance egg production. Dam et al. (1994) showed that heterotrophic feeding was responsible for $50 \%$ of in situ Acartia tonsa egg production in Long Island Sound. Klein Breteler et al. (1999) showed that Temora longicornis and Pseudocalanus elongatus could not be raised on a diet of the chlorophycean Dunaliella sp., which contained all essential amino acids but was deficient in highly unsaturated fatty acids and sterols. However, when the heterotrophic dinoflagellate Oxyrrhis marina grown on Dunaliella sp. was fed to T. longicornis and $P$. elongatus, both copepod species rapidly developed to maturity (Klein Breteler et al. 1999). Microzooplankton (ciliates and heterotrophic dinoflagellates) generally have a lower $\mathrm{C} / \mathrm{N}$ ratio than phytoplankton, and may contain other chemical constituents such as proteins, amino acids and fatty acids essential for copepod egg production (Stoecker \& Capuzzo 1990).

Nevertheless, Ederington et al. (1995) showed that Acartia tonsa egg production was 10-fold lower for ciliate-fed copepods than for diatom-fed copepods. The ciliate Pleuronema sp. did not contain a measurable amount of the polyunsaturated fatty acids 20:5 or 22:6, which have been suggested to be essential to the growth and development of marine animals (Enright et al. 1986), whereas the diatom Thalassiosira weissflogii did. Therefore, in our study, the high egg production on the ciliate (Strombidium sulcatum) diet may have been achieved because this ciliate contains at least some fatty acids and sterols, or because the copepod Centropages typicus converted them at low rates from other lipids. A few studies have also reported a negative impact of diatoms on egg production and hatching success (Poulet et al. 1994, Miralto et al. 1999), which could explain the low egg production with the T. weissflogii diet in our study. 


\section{Hatching success}

Our study did not reveal any strong correlation between diet or female age and hatching success. Previous work has shown that hatching success is mainly related to temperature (Smith \& Lane 1985) or female fecundity (Guisande \& Harris 1995); but the effects of food quantity and quality are less clear (Smith \& Lane 1985, Ianora et al. 1995, Miralto et al. 1995, Guerrero et al. 1997).

Hatching success in our study was lower than other published values. For example, Guerrero et al. (1997) found a $90 \pm 8 \%$ hatching success after $72 \mathrm{~h}$ for Centropages typicus feeding on Hymenomonas elongata. Smith \& Lane (1987) reported that $12 \%$ of eggs from C. typicus raised on Thalassiosira weissflogii did not hatch after more than $72 \mathrm{~h}$. They did not give any explanation for this observation, but their in situ data did not support the hypothesis of the production of resting eggs. Production of resting eggs has been reported for C. typicus (Lindley 1990) and for most of the Centropagidae (reviews: Uye 1985, Marcus \& Lutz 1998). Carlotti et al. (1997) described 2 kinds of eggs produced by C. typicus, with or without spines, specifying that the latter never hatched and that some of the eggs with spines also could not hatch. In their experiments (their Fig. 2), more than $61 \%$ of eggs did not hatch, suggesting that resting eggs are produced. The low hatching success in our study could be due to the production of resting eggs.

Ban (1992) suggested that conditions under which nauplii develop determine whether the resultant adults produce diapause eggs. Further studies have discussed the contentious issue of whether delays in hatching rates are due to food quality (Ianora et al. 1995, Jónasdóttir \& Kiørboe 1996, Tang et al. 1998). Tang et al. (1998) showed that copepod eggs can delay hatching for up to $11 \mathrm{~d}$ (mainly in response to a decrease in temperature), without necessarily being 'resting eggs'. Nevertheless, in our laboratory study, because of the similarity in hatching success and in hatching time between the different diets, and because $15.5 \%$ of the egg production had a total hatching success of $<75 \%$, and $64.3 \%$ of the eggs required $>3 \mathrm{~d}$ to hatch, whatever the diet, we believe that the low hatching success and long hatching time in our study resulted from the production of resting eggs rather than from any effect of food quality.

\section{Concluding remarks}

Using mainly experimental results on adults, the most recent compilation of data on zooplankton nutrition (Reports of GLOBEC Process Studies Working
Group, Roscoff, France) has underlined the importance of food quality to various zooplanktonic species. The present study highlights the need to examine the effect of food quality on the complete life cycle (i.e. the responses of different stages), since this cannot be generalised from adult data alone. To our knowledge, this study is one of the most complete to date, examining both growth and development simultaneously under different food conditions. Three major aspects should be borne in mind in future studies: (1) Weightlength relationships should be viewed with caution, since high variability in weight has been observed within the same stage of development dependant on food source. (2) Although mixed algae-ciliate diets seem to be the best food source for egg production, female survival and individual weight, the best results for growth, survival, ingestion, egg production rates, etc. were not always obtained for one and the same diet. (3) Optimal food concentration should not only be defined from ingestion rate, growth (weight), and development as in our study, but also using new approaches such as the RNA/DNA ratio, enzyme activities, etc. Since copepods change in size and behaviour during development, an approach based on determining optimal food concentrations for each development stage should be used.

Acknowledgements. The research work was supported by the Programme Réseau Diversité Marine (1998-2000) and the programme PNEC-ART2 (1998-1999) granted to F.C. D.B. was supported by the European project MTPII-MATER financed within the framework of the European Commission's MAST RTD programme under contract MAS3-CT96-0051 granted to F.C. We greatly appreciate the technical help of Vanessa Briano, and are grateful to Dr M. Koski, Dr R. P. Harris, Dr G. Tarling and S. Nival as well as the referees for their constructive comments on the manuscript.

\section{LITERATURE CITED}

Arnott GH, Brand GW, Kos LC (1986) Effects of food quality and quantity on the survival, development, and egg production of Gladioferens pectinatus (Brady) (Copepoda: Calanoida). Aust J Mar Freshw Res 37:467-473

Azam F, Fenchel T, Field JG, Gray JS, Meyer-Reil LA, Thingstad F (1983) The ecological role of water column microbes in the sea. Mar Ecol Prog Ser 10:257-263

Ban S (1992) Effects of photoperiod, temperature, and population density on induction of diapause egg production in Eurytemora affinis (Copepoda: Calanoida) in Lake Ohnuma, Hokkaido, Japan J Crustacean Biol 12:361-367

Berggreen U, Hansen B, Kiørboe T (1988) Food size spectra, ingestion and growth of the copepod Acartia tonsa during development: implications for determination of copepod production. Mar Biol 99:341-352

Bonnet D (1998) Estimation de l'ingestion des copépodes par différentes approches méthodologiques. Diplôme d' études supérieures, Université Paris VI

Butler M, Dam HG (1994) Production rates and characteristics of fecal pellets of the copepod Acartia tonsa under simu- 
lated phytoplankton bloom conditions: implications for vertical fluxes. Mar Ecol Prog Ser 114:81-91

Caparroy P (1998) Rôle de la turbulence dans les interactions entre le zooplancton et ses proies (phytoplancton et microzooplancton). Modélisation des processus, paramétrisation, expériences au laboratoire. Thèse 3ème cycle, Université Paris VI

Caparroy P, Pérez MT, Carlotti F (1998) Feeding behaviour of Centropages typicus in calm and turbulent conditions. Mar Ecol Prog Ser 113:110-115

Carlotti F, Nival S (1992) Moulting and mortality rates of copepods related to age within age experimental results. Mar Ecol Prog Ser 84:235-243

Carlotti F, Rey C, Javanshir A, Nival S (1997) Laboratory studies on egg and faecal pellet production of Centropages typicus: effect of age, effect of temperature, individual variability. J Plankton Res 19:1143-1165

Checkley DM (1980) The egg production of a marine planktonic copepod in relation to its food supply: Laboratory studies. Limnol Oceanogr 25:430-446

Corner EDS, Head RN, Kilvington CC, Marshall SM (1974) On the nutrition and metabolism of zooplankton. IX. Studies relating to the nutrition of over-wintering Calanus. J Mar Biol Assoc UK 54:319-331

Cowles TJ, Olson RJ, Chisholm SW (1988) Food selection by copepods: discrimination on the basis of food quality. Mar Biol 100:41-49

Dagg MJ, Grill DW (1980) Natural feeding rates of Centropages typicus females in the New York Bight. Limnol Oceanogr 25:597-609

Dam HG, Peterson WT, Bellantoni DC (1994) Seasonal feeding and fecundity of the calanoid copepod Acartia tonsa in Long Island Sound: is omnivory important to egg production? Hydrobiologia 292/293:191-199

Davis CS, Alatalo P (1992) Effects of constant and intermittent food supply on life-history parameters in a marine copepod. Limnol Oceanogr 37:1618-1639

Dolan JR, Marrasé C (1995) Planktonic ciliate distribution relative to a deep chlorophyll maximum: Catalan Sea, N.W. Mediterranean, June 1993) Deep-Sea Res Part I 42: 1965-1987

Durbin EG, Durbin AG, Smayda TJ, Verity PG (1983) Food limitation of production by adult Acartia tonsa in Narragansett Bay, Rhode Island. Limnol Oceanogr 28: $1199-1213$

Ederington MC, McManus GB, Harvey HR (1995) Trophic transfer of fatty acids, sterols, and a triterpenoid alcohol between bacteria, a ciliate, and the copepod Acartia tonsa. Limnol Oceanogr 40:860-867

Enright CT, Newkirk JS, Craigie JS, Castell JD (1986) Evaluation of phytoplankton as diet for juvenile Ostrea edulis L. J Exp Mar Biol Ecol 96:1-13

Frost BW (1972) Effects of size and concentration of food particles on the feeding behaviour of the marine planktonic copepod Calanus pacificus. Limnol Oceanogr 17:805-815

Fryd M, Haslund OH, Wohlgemuth O (1991) Development, growth and egg production of the two copepod species Centropages hamatus and Centropages typicus in the laboratory. J Plankton Res 13:683-689

Gorsky G, Dallot S, Sardou J, Fenaux R, Carré C, Palazzoli I (1988) C and $\mathrm{N}$ composition of some northwestern Mediterranean zooplankton and micronekton species. J Exp Mar Biol Ecol 124:133-144

Guerrero, F, Nival, S, Nival, P (1997) Egg production and viability in Centropages typicus: a laboratory study on the effect of food concentration. J Mar Biol Assoc UK 77: $257-260$
Guisande C, Harris RP (1995) Effect of total organic content of eggs on hatching success and naupliar survival in the copepod Calanus helgolandicus. Limnol Oceanogr 40: $476-482$

Hansen B, Bjørnsen PK, Hansen PJ (1994) The size ratio between planktonic predators and their prey. Limnol Oceanogr 39:395-403

Heinle DR, Harris RP, Ustach JF, Flemer DA (1977) Detritus as food source for estuarine copepods. Mar Biol 40:341-353

Ianora A, Poulet S (1993) Egg viability in the copepod Temora stylifera. Limnol Oceanogr 38:1615-1626

Ianora A, Poulet SA, Miralto A (1995) A comparative study of the inhibitory effect of diatoms on the reproductive biology of the copepod Temora stylifera. Mar Biol 121: $533-539$

Jónasdóttir SH, Kiørboe T (1996) Copepod recruitement and food composition: do diatoms affect hatching success? Mar Biol 125:743-750

Jónasdóttir SH, Fields D, Pantoja S (1995) Copepod egg production in Long Island Sound, USA, as a function of the chemical composition of seston. Mar Ecol Prog Ser 119: 87-98

Klein Breteler WCM, Fransz HG, Gonzaez SR (1982) Growth and Development of 4 calanoid copepod species under experimental and natural conditions. Neth J Sea Res 16: 195-207

Klein Breteler WCM, Schogt N, Gonzalez SR (1990) On the role of food quality in grazing and development of little stages, and genetic change of body size during cultivation of pelagic copepods. J Exp Mar Biol Ecol 135:177-189

Klein Breteler WCM, Gonzalez SR, Schogt N (1995) Development of Pseudocalanus elongatus (Copepoda, Calanoida) cultured at different temperature and food conditions. Mar Ecol Prog Ser 119:99-110

Klein Breteler WCM, Schogt N, Baas M, Schouten S, Kraay GW (1999) Trophic upgrading of food quality by protozoans enhancing copepod growth: role of essential lipids. Mar Biol 135:191-198

Klekowski RZ, Duncan A (1975) Physiological approach to ecological energetics. In: Grodzinski W, Klekowski RZ, Duncan A (eds) Methods for ecological bioenergetics. Blackwell Scientific Publishers, Oxford, p 15-64 (IBP Handbook No. 24)

Kleppel GS (1992) Environmental regulation of feeding and egg production by Acartia tonsa off southern California. Mar Biol 112:57-65

Kleppel GS (1993) On the diets of calanoid copepods. Mar Ecol Prog Ser 99:183-195

Koski M, Klein Breteler WCM, Schogt N (1998) Effect of food quality on rate of growth and development of the pelagic copepod Pseudocalanus elongatus (Copepoda, Calanoida). Mar Ecol Prog Ser 170:169-187

Landry MR (1975) The relationship between temperature and the development of life stages of the marine copepod Acartia clausi Giesbr. Limnol Oceanogr 20:854-857

Landry MR (1983) The development of marine calanoid copepods with comment on the isochronal rule. Limnol Oceanogr 28:614-624

Lindley JA (1990) Distribution of overwintering calanoid copepod eggs in sea-bed sediments around southern Britain. Mar Biol 104:209-217

Marcus NH, Lutz RV (1998) Longevity of subitaneous and diapause eggs of Centropages hamatus (Copepoda: Calanoida) from the northern Gulf of Mexico. Mar Biol 131: 249-257

Mauchline J (1998) The biology of calanoid copepods. Adv Mar Biol 33, Academic Press, London 
Mayzaud P, Tirelli V, Bernard JM, Roche-Mayzaud O (1998) The influence of food quality on the nutritional acclimatation of the copepod Acartia clausi. J Mar Syst 15:483-493

Miralto A, Ianora A, Poulet SA (1995) Food type induces different reproductive responses in the copepod Centropages typicus. J Plankton Res 7:1521-1534

Miralto A, Barone G, Romano G, Poulet SA, Ianora A, Russo GL, Buttino I, Laabir M, Cabrini M, Giacobbe MG (1999) The insidious effect of diatoms on copepod reproduction. Nature (Lond) 402:173-175

Müller-Navarra D (1995a) Evidence that a highly unsaturated fatty acid limits Daphnia growth in nature. Arch Hydrobiol 132:297-307

Müller-Navarra D (1995 b) Biochemical versus mineral limitation in Daphnia. Limnol Oceanogr 40:1209-1214

Ohman MD, Runge JA (1994) Sustained fecundity when phytoplankton resources are in short supply: omnivory by Calanus finmarchicus in the Gulf of St. Lawrence. Limnol Oceanogr 39:21-36

Ohman MD, Wood SN (1995) The inevitability of mortality. ICES, J Mar Sci 52:517-522

Paffenhöfer GA (1970) Cultivation of Calanus helgolandicus under controlled conditions. Helgol Wiss Meeresunters 20:346-359

Paffenhöfer GA (1971) Grazing and ingestion rates of nauplii, copepodids and adults of the marine planktonic copepod Calanus helgolandicus. Mar Biol 11:286-298

Paffenhöfer GA, Knowles SA (1980) Omnivorousness in marine planktonic copepods. J Plankton Res 2:355-365

Poulet SA, Ianora A, Miralto A, Meijer L (1994) Do diatoms arrest embryonic development in copepods? Mar Ecol Prog Ser 111:79-86

Razouls S (1977) Analyse pondérale, élémentaire et calorimétrique des stades juvéniles de copépodes pélagiques au cours d'une année. J Exp Mar Biol Ecol 26:265-273

Razouls C, Razouls S (1976) Dimensions, poids sec, valeur calorifique et courbes de croissance de deux populations naturelles de copépodes planctoniques en Méditerranée. Vie Milieu Ser B Oceanogr 26:281-297

Reinfelder JR, Fisher NS (1991) The assimilation of elements ingested by marine copepods. Science 251:794-796

Rey C, Harris R, Irigoien X, Head R, Carlotti F (2001) Influ-

Editorial responsibility: Otto Kinne (Editor),

Oldendorf/Luhe, Germany ence of food quality on growth and ingestion of Calanus helgolandicus nauplii. Mar Ecol Prog Ser 216:151-165

Smith SL, Lane PVZ (1985) Laboratory studies of the marine copepod Centropages typicus: egg production and development rates. Mar Biol 85:153-162

Smith SL, Lane PVZ (1987) On the life history of Centropages typicus: responses to a fall diatom bloom in the New York Bight. Mar Biol 95:305-313

Stoecker DK, Capuzzo JM (1990) Predation on protozoa: its importance to zooplankton. J Plankton Res 12:891-908

Stoecker DK, Egloff DA (1987) Predation by Acartia tonsa Dana on planktonic ciliates and rotifers. J Exp Mar Biol Ecol 110:53-68

Stoecker DK, Govoni JJ (1984) Food selection by larval gulf menhaden (Brevoortia patronus). Mar Biol 80:299-306

Støttrup JG, Jensen J (1990) Influence of algal diet on feeding and egg-production of the calanoid copepod Acartia tonsa Dana. J Exp Mar Biol Ecol 141:87-105

Tang KW, Dam HG (1999) Limitation of zooplankton production: beyond stoichiometry. Oikos 84:537-542

Tang KW, Dam HG, Feinberg LR (1998) The relative importance of egg production rate, hatching success, hatching duration and egg sinking in population recruitment of two species of marine copepods. J Plankton Res 20: 1971-1981

Twombly S, Burns C (1996) Effects of food quality on individual growth and development in the freshwater copepod Boeckella triarticulata. J Plankton Res 18:2179-2196

Twombly S, Clancy N, Burns CW (1998) Life history consequences of food quality in the freshwater copepod Boeckella triarticulata. Ecology 79:1711-1724

Urabe J, Watanabe Y (1992) Possibility of N or P limitation for planktonic cladocerans: an experimental test. Limnol Oceanogr 37:244-251

Uye SI (1985) Resting egg production as a life history strategy of marine planktonic copepods. Bull Mar Sci 37:440-449

Wiadnyana NN, Rassoulzadegan F (1989) Selective feeding of Acartia clausi and Centropages typicus on microzooplankton. Mar Ecol Prog Ser 53:37-45

Williamson CE, Butler NM (1986) Predation on rotifers by the suspension-feeding calanoid copepod Diaptomus pallidus. Limnol Oceanogr 31:393-402

Submitted: September 1, 2000; Accepted: April 5, 2001 Proofs received from author(s): November 30, 2001 